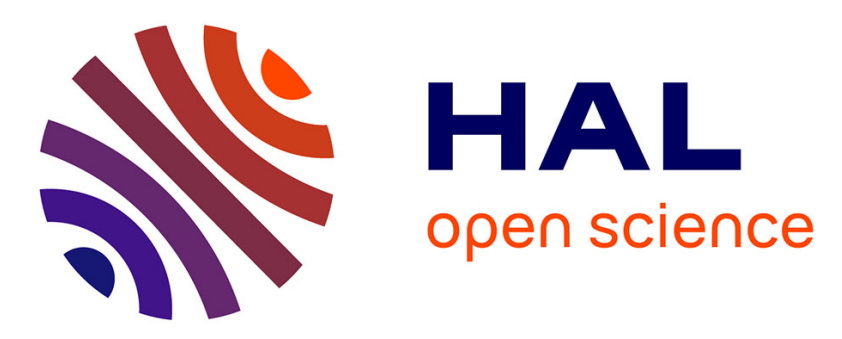

\title{
An overview of bacterial diseases of the most important agricultural crops in Nepal
}

Jay Ram Lamichhane, Giorgio M. Balestra, Angelo Mazzaglia, Mb Kshetri, Leonardo Varvaro

\section{- To cite this version:}

Jay Ram Lamichhane, Giorgio M. Balestra, Angelo Mazzaglia, Mb Kshetri, Leonardo Varvaro. An overview of bacterial diseases of the most important agricultural crops in Nepal. 28. International Horticultural Congress on Science and Horticulture for People (IHC2010): International Symposium on Plant Protection, Aug 2010, Lisbonne, Portugal. 324 p., 10.17660/ActaHortic.2011.917.26 . hal02745400

\section{HAL Id: hal-02745400 \\ https: / hal.inrae.fr/hal-02745400}

Submitted on 3 Jun 2020

HAL is a multi-disciplinary open access archive for the deposit and dissemination of scientific research documents, whether they are published or not. The documents may come from teaching and research institutions in France or abroad, or from public or private research centers.
L'archive ouverte pluridisciplinaire HAL, est destinée au dépôt et à la diffusion de documents scientifiques de niveau recherche, publiés ou non, émanant des établissements d'enseignement et de recherche français ou étrangers, des laboratoires publics ou privés. 


\title{
An Overview on Bacterial Diseases of the Most Important Agricultural Crops in Nepal
}

\author{
J.R. Lamichhane ${ }^{1,2}$, G.M. Balestra ${ }^{1,2}$, A. Mazzaglia ${ }^{1}$ M.B. Kshetri ${ }^{2}$ and L. Varvaro ${ }^{1,2}$ \\ ${ }^{1}$ Dipartimento di Protezione delle Piante, Facoltà di Agraria, Università degli Studi della \\ Tuscia, 01100, Viterbo, Italy \\ ${ }^{2}$ Central Horticulture Centre, Kirtipur, Kathmandu, Nepal
}

Keywords: bacterial diseases, plant crops, Nepal, yield loss

\begin{abstract}
Several surveys were carried out during three consecutive years (2007-2009) on the major crops cultivated in different districts of Nepal, in order to verify the possible presence of diseases caused by bacteria. The monitoring was carried out twice a year, in spring and autumn. During the survey we observed a wide range of bacterial diseases of plants. Most of the diseases were observed for the first time while others had been reported previously. Among the bacterial diseases observed for the first time, the most important were olive knot, bacterial speck of tomato, crown gall of plum, soft rot of potato, bacterial spot of tomato, and bacterial spot of cucurbits. Outbreaks of black rot were observed in different Brassica fields. Among the other widespread diseases, the most important were bacterial leaf blight of rice, citrus canker, citrus greening, bacterial wilt of tomato, potato, pepper, and eggplant, halo blight of bean, and bacterial pustule and bacterial blight of soybean. Attempts to explore the source of introduction of these pathogens, their spread, and yield losses caused were made together with recommendations for control measures.
\end{abstract}

\section{INTRODUCTION}

Agriculture in Nepal has long been based on subsistence farming, particularly in the hilly regions where peasants derive their living from fragmented plots of land cultivated in difficult conditions. Only 30\% of the total land in Nepal is cultivated since the major part of the land is occupied by mountains and hills. For this reason, almost all the harvested crops are aimed at family use and farmers only export some surplus which is the main source of their income (Schroeder, 1985). The main cultivated plants are represented by rice, 1.5 million ha, followed by wheat and maize, which together take up a similar portion of the cultivated land, and thirdly by cash crops (sugarcane, oilseed, tobacco, and vegetables) that are very important for Nepalese farmers because of the good economic returns.

Agricultural crops are threatened by a wide variety of pathogens and pests all over the world. Several studies have been made in developed countries to find out the relationship between the presence of the plant pathogens and the potential yield losses caused by them. Nevertheless, very little is known about the plant diseases and yield losses in Nepal, in particular, those caused by the bacterial pathogens, since very few studies have been carried out until recently. Moreover, comparison of the average yield of plant crops with other developed and developing countries shows a big gap between potential yield and actual yield of Nepalese farmers (FAO, 2008). This low productivity is associated with a number of reasons. Among them, plant diseases are the most important factors.

Our aim was to carry out a wide survey to verify whether there are new plant diseases, and to provide complete information on their control using effective measures, on the most important agricultural plants cultivated in Nepal. Our study focused mainly on the vegetable crops since these are considered important cash crops due to the fact that their cultivation in many areas of Nepal is almost continuous, with up to three crops per year (Anonymous, 2006). 


\section{MATERIALS AND METHODS}

\section{Surveyed Zones and Plant Species}

Many commercial fields and home gardens were surveyed in all the three major agricultural zones (high hills, mid hills, and plain land) of Nepal. The plant species surveyed and districts where we carried out the investigations are shown in Table 1.

\section{Collection of Infected Plants and Bacterial Identification}

During the survey, only plants showing characteristic bacterial disease symptoms were considered. The diseased parts of the plants were aseptically collected, put into sterile laboratory bags, and taken immediately to the laboratory and stored at $4^{\circ} \mathrm{C}$. Within two days of sampling, bacteria were isolated from the diseased tissues on to selective or semi-selective media and incubated at $26 \pm 1^{\circ} \mathrm{C}$ to determine the possible causal agents. After 48-72 h, single bacterial colonies were purified. Identification of the bacterial isolates was made by morphological, physiological, biochemical, molecular, and pathogenicity tests.

\section{Determination of Disease Incidence and Yield Loss}

The number of surveyed fields and the presence of given diseases in those fields was taken into account. Disease incidence was calculated as the ratio between the number of surveyed fields and the number of fields where a given disease was found. The yield losses caused by the bacterial pathogens were calculated by the relationship between the average potential yield of a certain field from a given zone in the absence of the disease and that effectively obtained from a field where disease was present (Burlakoti and Khatri-Chhetri, 2004) (Table 2).

\section{Collection of Information on Diseases Previously Reported}

Besides our study, information was collected on the bacterial diseases previously found and reported by other authors and is shown in Table 3.

\section{RESULTS}

\section{Surveyed Districts and Plant Species}

Surveys were carried out in districts particularly important for different plant cultivation. In many cases, attention was paid to particular districts based on information provided by previous authors for the phytobacteriological investigation (Table 1).

\section{Collection of Infected Plants and Bacterial Identification}

During the surveys, characteristic symptoms of bacterial diseases were observed in all the districts where investigations were made (Table 2), except in some districts where the presence of the diseases was not verified (Fig. 1). The assays performed for the identification of the pathogens are listed in Table 4.

\section{CONCLUSIONS}

In the present study we report a wide range of bacterial diseases of plants for the first time in Nepal such as olive knot, bacterial speck of tomato, crown gall of plum, soft rot of potato, bacterial spot of tomato, and bacterial spot of pumpkin. On the other hand, this study supports previous findings confirming that bacterial diseases are widespread in different districts of the country and are becoming a serious problem.

The presence of the newly reported diseases indicates the possible introduction of the bacterial pathogens via infected seed, transplants, and other vegetative materials used for plant propagation from other countries, including those neighbouring countries where these pathogens have been widely reported. The considerable economic losses caused by these diseases and their wide host range represent a serious concern for an undeveloped country like Nepal where the role of agriculture is of fundamental importance since it is a 
main source of income. The control measures of quarantine pest and disease management, and the agronomical and cultural practices for disease prevention within the country are not effective and targeted to disease control. Therefore, the introduction of new plant pathogens into the country and the spread of those already present from one region to another occur continuously and can be a serious threat for Nepalese agriculture.

Only some bacterial diseases such as bacterial blight of rice (Adhikari and Mew, 1988; Adhikari and Shrestha, 1989; Adhikari et al., 1996, 1999a,b), black rot of Brassica (Adhikari and Basnyat, 1999; Jensen et al., 2010; Shakya et al., 2000; Shrestha, 1997; Shrestha and Mathur, 1977), and bacterial wilt of potato (Pradhanang et al., 1993, 2000; Pradhanang and Elphinstone, 1996; Shrestha, 1977; Shrestha et al., 1977), have been an important focus of study by many authors who provided detailed information on the disease severity, yield loss, spread, and the diversity of the bacterial pathogens. Either no or limited attention has been paid to other bacterial pathogens, in particular the bacterial pathogens of those vegetable crops which represent important cash crops for the livelihood of Nepalese farmers (Burlakoti and Khatri-Chhetri, 2004; Subedi and KhattriChettri, 2004).

Our study confirms that the average disease incidence and yield losses caused by bacterial pathogens in Nepal are very high. For this reason, immediate control measures are necessary to avoid the spread of bacterial pathogens from one region to another, and to eradicate them from districts where the diseases are threatening agricultural production. Nevertheless, there are many areas of the country that still need to be surveyed for the presence of bacterial pathogens and may provide several new findings. A thorough study will be needed to collect detailed information that will be helpful for future research on bacterial diseases of crop plants in Nepal.

\section{Literature Cited}

Adhikari, T.B. and Basnyat, R. 1999. Phenotypic characteristics of Xanthomonas campestris pv. campestris from Nepal. European Journal of Plant Pathology 105:303305.

Adhikari, T.B. and Mew, T.W. 1988. Research on bacterial blight of rice in Nepal. p.98. In: Proc. $5^{\text {th }}$ Int. Congr. Plant Pathol.

Adhikari, T.B. and Shrestha, S.M. 1989. Distribution and severity of bacterial blight of rice in Nepal. J. Inst. Agric. Anim. Sci. 10:31-38.

Adhikari, T.B., Basnyat, R.C. and Mew, T.W. 1999a. Virulence of Xanthomonas oryzae pv. oryzae on rice lines containing single resistance genes and gene combinations. Plant Dis. 83:46-50.

Adhikari, T., Leach, J. and Mew, T.W. 1996. Bacterial blight of rice and its control in Nepal. Integr. Pest Management Rev. 1:91-95.

Adhikari, T.B., Manandhar, J.B. and Hartman, G.L. 1993. Characterization of Pseudomonas solanacearum and evaluation of tomatoes in Nepal. p.132-137. In: G.L. Hartman and A.C. Hayward (eds.), Bacterial wilt. Proceedings of an International Conference held at Kaohsiung, Taiwan.

Adhikari, T.B., Mew, T.W. and Leech, J.E. 1999b. Genomic and pathogenic diversity in Xanthomonas orizae pv. orizae in Nepal. Phytopathology 89:687-694.

Anonymous. 2006. Annual Report. Vegetable Development Directorate, Department of Agriculture, Khumaltar, Lalitpur, Nepal.

Balestra, G.M., Lamichhane, J.R., Kshetri, M.B., Mazzaglia, A. and Varvaro, L. 2009. First report of Pseudomonas savastanoi pv. savastanoi on olive in Nepal. Plant Pathology 58:393.

Burlakoti, R.R. and Khatri-Chhetri, G.B. 2004. Bacterial diseases of crop plants in Nepal, a review. J. Inst. Agric. Anim. Sci. 25:1-10.

CMI. 1978. Distribution Maps of Plant Diseases No. 11 (edition 5). CAB International, Wallingford, UK (Citrus canker).

Dhakal, D.D., Gotame, T.P., Bhattarai, S. and Bhandari, H.N. 2008. Assessment of lime and lemon production in Nepal. J. Inst. Agric. Anim. Sci. 23:49-58. 
FAO. 2008. http://faostat.fao.org/site/567/DesktopDefault.aspx?PageID=567.

IMI. 1996. Distribution Maps of Plant Diseases No. 401 (edition 3). CAB International, Wallingford, UK. (X. campestris pv. phaseoli).

Jensen, B.D., Vicente, J.G., Manandhar, H.K. and Roberts, S.J. 2010. Occurrence and diversity of Xanthomonas campestris pv. campestris in vegetable Brassica fields in Nepal. Plant Disease 94(3):298-305.

Lamichhane, J.R., Kshetri, M.B., Mazzaglia, A., Varvaro, L. and Balestra, G.M. 2009. Bacterial speck caused by Pseudomonas syringae pv. tomato race 0: first report in Nepal. Plant Pathology 59:401.

Lamichhane, J.R., Mazzaglia, A., Kshetri, M.B., Varvaro, L. and Balestra, G.M. 2009. First report of crown gall of Prunus spp. caused by Agrobacterium tumefaciens biovar 1 in Nepal. Journal of Plant Pathology 91(4S):112.

Lamichhane, J.R., Balestra, G.M. and Varvaro, L. 2010. Occurrence of soft rot of potato caused by Erwinia carotovora subsp. carotovora in Nepal: a first report. Plant Disease 94(3):382.

Lamichhane, J.R., Balestra, G.M. and Varvaro, L. 2010. First report of bacterial spot caused by Xanthomonas campestris pv. vesicatoria race 2 in Nepal. New Disease Report 21 (in press).

Lamichhane, J.R., Varvaro, L. and Balestra, G.M. 2010. Bacterial leaf spot caused by Xanthomonas cucurbitae newly reported on pumpkin in Nepal. New Disease Report 21 (in press).

OEPP/EPPO. 1978. Data sheets on quarantine organisms Nos 60 \& 61, Xanthomonas phaseoli var. phaseoli and var. fuscans. Bulletin OEPP/EPPO Bulletin 8(2).

OEPP/EPPO. 1978. Data sheets on quarantine organisms No. 57, Pseudomonas syringae pv. pisi. Bulletin OEPP/EPPO Bulletin 8(2).

OEPP/EPPO. 1990. Quarantine procedures No. 27. Xanthomonas campestris pv. citri. Inspection test and survey methods. Bulletin OEPP/EPPO Bulletin 20:263-272.

Pradhanang, P.M., Pandey, R.R., Ghimire, S.R., Dhital, B.K. and Subedi, A. 1993. An approach to management of bacterial wilt of potato through crop rotation and farmers' participation. p.362-370. In: G.L. Hartman and A.C. Hayward (eds.), Bacterial Wilt. ACIAR Proceedings No. 45. Canberra, Australia: ACIAR.

Pradhanang, P.M. 1998. Bacterial wilt of potato caused by Ralstonia solanacearum biovar 2: a study of the ecology and taxonomy of the pathogen in Nepal. Ph.D. thesis, Reading, UK: University of Reading.

Pradhanang, P.M. and Elphinstone, J.G. 1996. Identification of weed and crop hosts of Pseudomonas solanacearum race 3 in the hills of Nepal. In: P.M. Pradhanang and J.G. Elphinstone (eds.), Integrated management of bacterial wilt of potato: Lessons from the hills of Nepal. Proceedings of a National Workshop held at Lumle Agricultural Research Centre, Pokhara, p.39-49.

Pradhanang, P.M., Elphinstone, J.G. and Fox, R.T.V. 2000. Identification of crop and weed hosts of Ralstonia solanacearum biovar 2 in the hills of Nepal. Plant Pathology 49:403-413.

Regmi, C. and Lama, T.K. 1988. Greening incidence and greening vector population dynamics in Pokhara. p.238-242. In: Proc. $10^{\text {th }}$ Conf. IOCV, IOCV, Riverside.

Schroeder, R.F. 1985. Himalayan subsistence systems indigenous agriculture in rural Nepal. Mountain Research and Development 5(1):31-44.

Shakya, D.D., Louws, F.J. and Alvarez, A.M. 2000. Diversity of Xanthomonas campestris pv. campestris (Xcc) populations in Nepal. Phytopathology 90:71.

Sharma, R.C., De Leon, C. and Payak, M.M. 1993. Diseases of maize in south and southeast Asia, problems and progress. Crop Protection 12:414-422.

Shrestha, K. 1997. A list of seed-borne organisms in Nepal. Nepalese J. Agric 12:217224.

Shrestha, S.K. 1977. Preliminary study on brown rot of potatoes in Nepal. Nepalese J. Agric 12:11-21.

Shrestha, K., Mathur, S.B. and Neergaard, P. 1977. Seed-borne organisms in some crops 
of Nepal. Seed Science Technology 5:111-121.

Subedi, G.D. and Khattri-Chettri, R.B. 2004. Scenario of hybrid vegetable seed use in Nepal. p.275-281. In: B.B. Khattri, B.P. Sharma, P.P. Khatiwada, K.P. Paudyal, B.R. Khadge, and H.N. Regmi (eds.), Advances of Horticultural Research in Nepal. Proc. Fourth Natl. Workshop Horticulture, Nepal Agricultural Research Council, National Research Insitute and Horticulture Research Division, Khumaltar, Lalitpur, Nepal.

\section{$\underline{\text { Tables }}$}

Table 1. List of surveyed plant species and districts.

\begin{tabular}{|c|c|}
\hline Crop & Surveyed districts \\
\hline $\begin{array}{l}\text { Brassica } \\
\text { vegetables* } *^{\dagger} \\
\text { (cabbage, } \\
\text { cauliflower and } \\
\text { broccoli) }\end{array}$ & $\begin{array}{c}\text { Bhaktapur, Lalitpur, Chitwan, Dhankuta, Baglung, Nuwakot, } \\
\text { Kathmandu, Makwanpur }\end{array}$ \\
\hline Potato $^{* T^{\top}}$ & Kathmandu, Nuwakot, Bhaktapur, Lalitpur, Kaski \\
\hline Tomato* $^{\top}$ & Kathmandu, Lalitpur, Banke \\
\hline Pumpkin* & Kathmandu, Lalitpur, Bhaktapur \\
\hline $\operatorname{Bean}^{* \top}$ & Kathmandu, Dhading \\
\hline Soybean*T & Nuwakot, Kathmandu \\
\hline Pepper* ${ }^{\top}$ & Kathmandu, Nuwakot, Bhaktapur, Lalitpur, Kaski \\
\hline Eggplant $*^{\top}$ & Kathmandu, Nuwakot, Bhaktapur, Lalitpur, Kaski \\
\hline Rice*T $^{* \top}$ & $\begin{array}{l}\text { Ilam, Jhapa, Dhankuta, Bhojpur, Sunsari, Dhanusha, Sarlahi, } \\
\text { Makwanpur, chitwan, Bara, Parsa, Palpa, Gulmi, Kaski, Lamjung, } \\
\text { Tanahu, Gularia, Dang, Pyuthan, Nuwakot }\end{array}$ \\
\hline Maize $^{* \top}$ & Kathmandu, Nuwakot, Bhaktapur, Lalitpur, Kaski \\
\hline $\mathrm{Pea}^{\top}$ & Chittwan, Nuwakot, Bhaktapur, Lalitpur, Kaski \\
\hline Plum* & Kathmandu, Nuwakot, Gorkha \\
\hline Citrus $^{\top \top}$ & Kathmandu, Nuwakot, Gorkha, Kavre, Kaski, Sindhuli \\
\hline Olive* & Bajura, Mugu, Dolpa, Kathmandu, Makwanpur \\
\hline
\end{tabular}

*these studies; ${ }^{\dagger}$ previous studies. 
Table 2. Incidence of bacterial diseases of plants in the surveyed districts.

\begin{tabular}{lcc}
\hline Disease & Causal bacterial agent & Incidence \\
\hline Black rot of Brassica spp. & Xanthomonas campestris pv. campestris & High \\
Soft rot of potato & Pectobacterium carotovorum & Medium \\
Bacterial wilt of potato & Ralstonia solanacearum & Medium \\
Bacterial speck of tomato & Pseudomonas syringae pv. tomato & Low \\
Bacterial spot of tomato & Xanthomonas campestris pv. vesicatoria & Low \\
Bacterial wilt of tomato & Ralstonia solanacearum & Very high \\
Bacterial spot of pumpkin & Xanthomonas campestris pv. cucurbitae & Low \\
Bacterial wilt of eggplant & Ralstonia solanacearum & Medium \\
Bacterial wilt of pepper & Ralstonia solanacearum & High \\
Common blight of bean & Xanthomonas campestris pv. phaseoli & Medium \\
Halo blight of bean & Pseudomonas syringae pv. phaseolicola & Medium \\
Bacterial blight of soybean & Pseudomonas syringae pv. glycinea & Medium \\
Bacterial pustule of soybean & Xanthomonas campestris pv. glycines & Medium \\
Bacterial blight of pea & Pseudomonas syringae pv. pisi & Medium \\
Bacterial blight of rice & Xanthomonas orizae pv. orizae & High \\
Crown gall of plum & Agrobacterium tumefaciens & High \\
Olive knot & Pseudomonas savastanoi pv. savastanoi & Low \\
Citrus canker & Xanthomonas campestris pv. citri & Very high \\
Citrus greening & Liberobacter asiaticum & Very high \\
Bacterial wilt of tobacco & Ralstonia solanacearum & High \\
Bacterial stalk rot of maize & Erwinia chrysanthemi & high \\
\hline Low: $<20 \% ;$ medium: $<20-40 \% ;$ high: $40-60 \% ;$ very high: $>$ 60\%. &
\end{tabular}


Table 3. List of reported disease and yield loss caused by the pathogens.

\begin{tabular}{lcc}
\hline Disease & Reference & Average yield loss (\%) \\
\hline Black rot of brassica & Shrestha and Mathur, 1977 & 40 \\
Soft rot of potato & Lamichhane et al., 2010 & 20 \\
Bacterial wilt of potato & Shrestha, 1977 & 75 \\
Bacterial speck of tomato & Lamichhane et al., 2009 & 18 \\
Bacterial spot of tomato & Lamichhane et al., 2010 & 25 \\
Bacterial wilt of tomato & Adhikari et al., 1993 & 90 \\
Bacterial wilt of eggplant & Adhikari et al., 1993 & 32 \\
Bacterial wilt of pepper & Adhikari et al., 1993 & 90 \\
Bacterial spot of pumpkin & Lamichhane et al., 2010 & 12 \\
Common blight of bean & OEPP/EPPO, 1978 & 16 \\
Halo blight of bean & Burlakoti and Khatri-Chhetri, 2004 & 16 \\
Bacterial blight of pea & OEPP/EPPO, 1978 & 13 \\
Bacterial blight of soybean & Burlakoti and Khatri-Chhetri, 2004 & 16 \\
Bacterial pustule of soybean & Burlakoti and Khatri-Chhetri, 2004 & 23 \\
Bacterial blight of rice & Adhikari and Mew, 1988 & 32 \\
Crown gall of plum & Lamichhane et al., 2009 & 60 \\
Olive knot & Balestra et al., 2009 & 25 \\
Citrus canker & OEPP/EPPO, 1990 & 90 \\
Citrus greening & Regmi and Lama, 1988 & 92 \\
Bacterial wilt of tobacco & Adhikari et al., 1993 & 35 \\
Bacterial stalk rot of maize & Burlakoti and Khatri-Chhetri, 2004 & 75 \\
\hline
\end{tabular}

Table 4. List of assays used for the identification of bacterial species.

\begin{tabular}{cl}
\hline Morphological and cultural & Physiological and biochemical \\
Form & Levan production \\
Colony colour & Fluorescence test \\
Colony margin & Oxidase production \\
Colony dimension & Potato soft rot \\
Molecular & Arginine hydrolysis \\
16SrDNA & Aesculin hydrolysis \\
Pathogenicity test & $\mathrm{H}_{2} \mathrm{~S}$ production \\
In vivo - by using a bacterial suspension & Carbon source utilization \\
containing $10^{8} \mathrm{CFU} / \mathrm{ml}$ & Phosphatase test \\
& Gram test \\
\hline
\end{tabular}




\section{Figures}

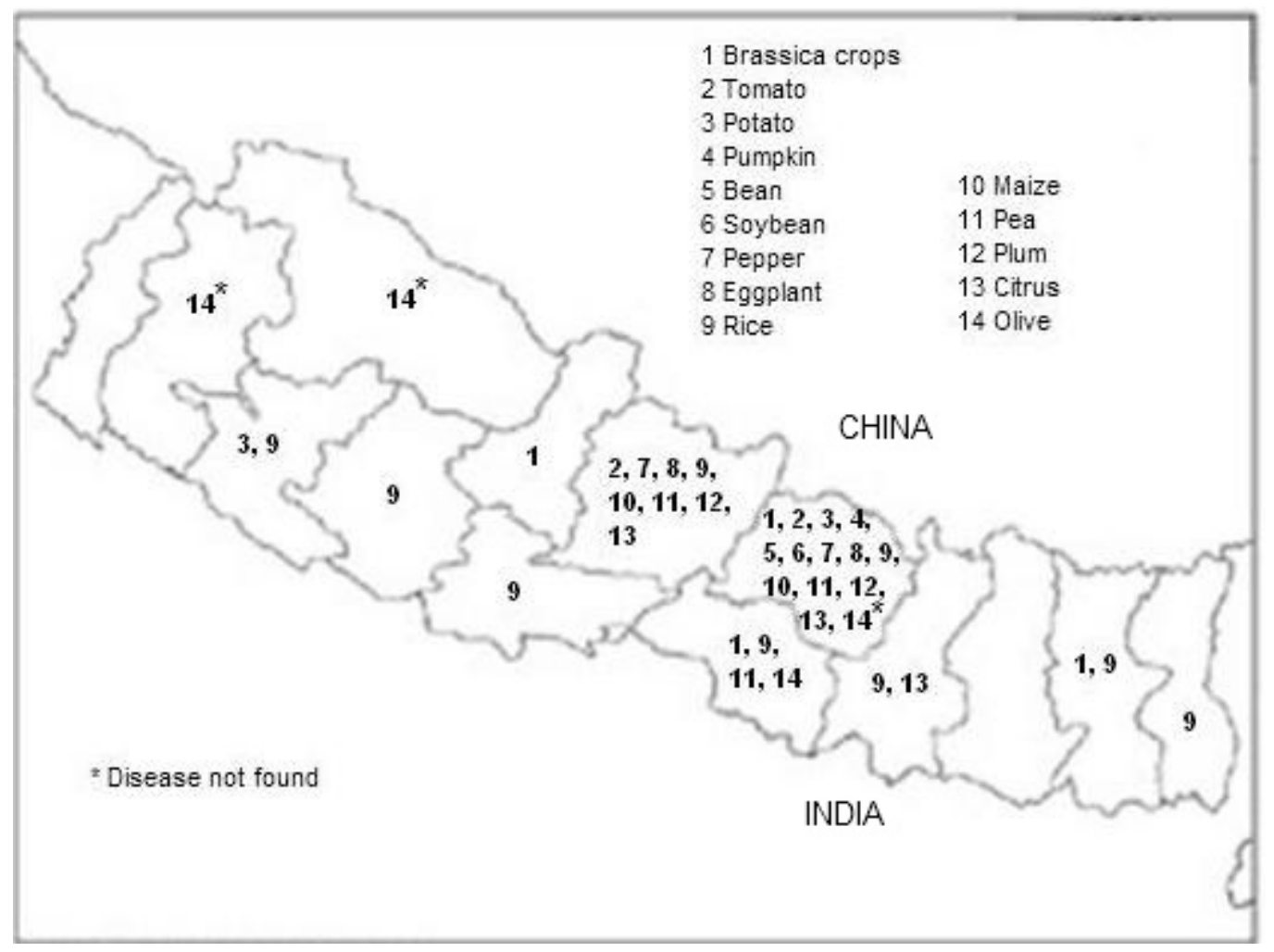

Fig. 1. Map of surveyed zones and plant species. 